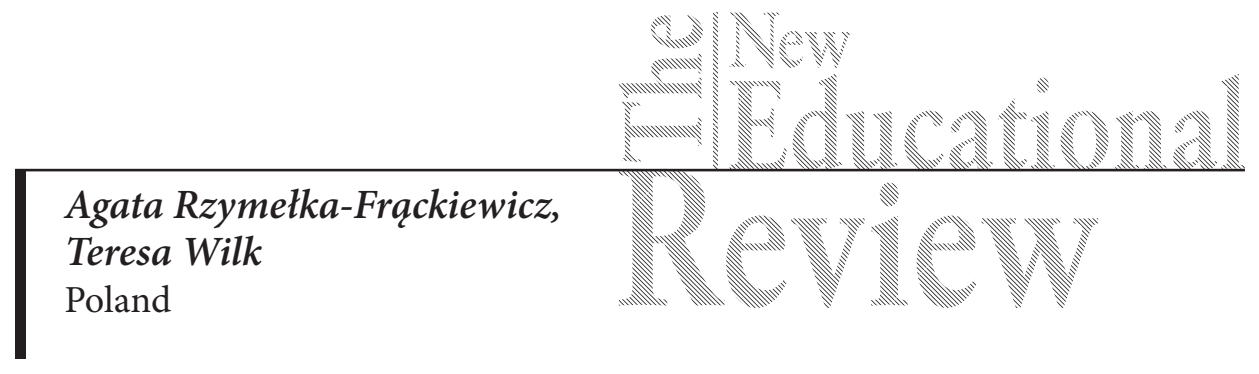

\title{
The Idea of Lifelong Learning - Polish Experience and Reality
}

DOI: 10.15804/tner.2015.42.4.18

\begin{abstract}
When planning for a year, plant corn.
When planning for a decade, plant trees.

When planning for life, train and educate people
\end{abstract}

(Bauman, 2012, p. 26) ${ }^{1}$

\begin{abstract}
The presented study addresses the issue of the concept of lifelong learning based on Polish experience, on the basis of the latest research: the international programme: Programme for the International Assessment of Adult Competencies (Study on an international scale, realised for the first time in Poland on a sample of more than 9 thousand people) and Polish reports: Report on the State of Education 2013 - Teachers Matter, and Social Diagnosis 2013 - the Labour Market and Social Exclusion in the Context of the Perception of Poles.

The presented study and the authors' considerations revolve around the concepts of: learning, schooling, undertaking educational activity by adults, which, as clearly indicated by the research results, constitutes an insignificant part of Polish society. This situation puts our country on one of the last places in the ranking of highly developed countries.
\end{abstract}

Keywords: education, the idea of lifelong learning, modern personality, characteristics of modernised societies, civilization competence, educational research: PISA, PIAAC, Social Diagnosis 2013, Report on the State of Education 2013

1 A Chinese proverb quoted by Zygmunt Bauman. 


\section{Introduction}

Development of education in contemporary conditions is an indicator of the level of achieved social, cultural and economic development, which becomes an investment in the future, one of the important measures of achieving the desired quality of life, as well as the possibility of playing an active role in all dimensions of social, public life. Educational and vocational preparation implies the possibility of undertaking innovative projects, and the development of independence, and creative activity of individuals in different areas of life (Szempruch, 2012, p. 152) in societies globalising themselves. Experienced modernity introduces changes, and leads to the generation of a specific type of modern man, who is forced by external factors, and often also by his own internal motivation, and cannot remain indifferent to the idea of lifelong learning.

\section{Modern personality}

One of the best recognised concepts of "modern personality" was created in the 70s of the twentieth century by an American social psychologist Alex Inkeles, who came up with the assumption that the personality of people living in modern society is significantly influenced by four factors: the degree of urbanisation, industrialisation, social mobility, and mass communication and culture (Inkeles, as cited in: Sztompka, 2002, p. 565). In the presented considerations the concept of modern personality syndrome is worth paying attention to. This category includes nine personality traits:

- openness to innovation and change, the need for new experiences,

- readiness to express and justify one's own opinions, while tolerating distinct opinions, and even finding satisfaction in such a diversity;

- prospective orientation to time, focused on the future rather than the past, and highlighting the virtue of punctuality,

- the feeling of subjective power, i.e., the belief that the challenges and problems, both personal and social, will allow for resolving themselves under the condition of taking, individually or jointly, appropriate actions,

- anticipation of future events and planning future actions, and therefore the involvement of imagination in order to properly set oneself up towards the future,

- confidence in the social order, the belief in the accuracy, predictability and calculability of social life thanks to the existence of fixed and enforced rules 
of business transactions, the policy of the state, as well as mores and moral rules that shape everyday activities of citizens,

- a sense of "distributive justice", i.e., the recognition of unequal distribution of wealth, the value of privileges, as long as they are not arbitrary or adjusted by clear principles, in particular the meritocratic principle demanding unequal remuneration of unequal merits,

- attaching great importance to education, training, self-improvement,

- respecting the dignity of others even those with lower social status or remaining in relations of subordination (Inkeles, as cited in: Sztompka, 2002, pp. 565-567).

According to Inkeles, not only do the conditions of modern society shape each of these personality traits individually, but each of these traits, once formed, supports and reinforces the others, leading to the emergence of a coherent personality type. Hence, there is a need to create education systems that take up the task of purposeful shaping of the desired types of personality.

On the other hand, in Polish literature we find the stance of Krystyna Ferenz, who believes that the man of the twenty-first century should be an autonomous personality, with a flexible mentality, distinguishing boundaries of needed adaptation and necessary innovation, understanding the need for and the terms of subordination of choice or necessity, but also to govern oneself and the others (Ferenz, Walasek Ed. 2009, pp. 347-356). The image of modern personality, of rational, progressive man, is seen as one of the classic conditions for the successful development of modern society in the era of globalisation. It is an attempt to construct a role model useful for creators of all socialisation and educational processes of the present day. The record of such traits was aptly drawn by Marek Szczepański, who noted the register of traits attributed to modernised societies; what follows is that the most important characteristics of modern personality include:

- extensive need for achieveing,

- a high level of empathy, and

- nonconformity.

One can assume that people strongly motivated by the need for achieving are characterised by at least four special traits:

- constant tendency to take risks and concurrent awareness of their consequences,

- predisposition to innovation,

- capability of analytical assessment of undertaken activities completed with both success and failure, 
- complete internal mobilisation in terms of competition, ensuring achieving very good results (Szczepański, 1999, pp. 272-273).

Everyday life requires having civilization competences. Piotr Sztompka, therefore, rightly ascribes these attributes to modern man. The author suggests understanding the term "civilisation competence" as deep-rooted (internalised) habits, skills and reflexes, etc., necessary for the full use of institutions, organisational forms, ways of life, as well as technical equipment that have been created in the context of modern industrial civilization (Sztompka, 1997; Sztompka, 1999). Acquisition of modern personality traits, of civilization competences, becomes a chance of a lifetime of every individual for the full and active participation in social life.

From the point of view of the education systems it seems legitimate to attempt at sketching the map of desirable competences of modern man, so that the school should educate individuals with competences relevant to the post-industrial reality. Contemporarily, education is generally considered a "good thing", and most people who have passed through the system of education and learned to write and count, and have acquired the desirable knowledge, would agree that education has clear benefits. However, the process itself, especially compulsory education, is not without its faults. "Sociologists distinguish between education and schooling. Education can be defined as a certain social institution enabling and promoting the acquisition of skills and knowledge, and expansion of personal horizons, which can happen in a variety of different conditions. In contrast, schooling is a formal process during which certain types of knowledge and skills belonging to a predetermined program are transmitted; schooling understood as such is mandatory for people up to a certain age (Giddens, Sutton, 2014, pp. 103-104)". By adopting such definition solutions, lifelong learning should be considered as education whose part is schooling.

The challenges of today and the upcoming future are the reason why education in the broad sense should prepare people for using current developments of changing civilization, but also involve them in creative and independent participation in social life. The mission of education in the contemporary, global, information society is to create the conditions for all, without exception, for revealing their talents and creative abilities. It requires everyone to be responsible for themselves and realize their life plans. The well-known and respected Report of the International Commission on Education for the $21^{\text {st }}$ Century, chaired by Jacques Delors - Learning: the Treasure Within, stresses the importance of education. The authors of the report believe that education, in order to fulfil its mission, should be organised around four aspects of education: 
- Learn to know, which is not about gathering encyclopaedic and codified information, but about mastering the tools of knowledge, about equipping with tools, concepts and methods of references, relevant to the advancement of knowledge and paradigms of the era;

- Learn to do, while it is not the point in this statement to prepare the individual to perform a specific task, but to develop skills for using the advancement of knowledge in the application of innovation, in solving problems, it is about skills known as competences;

- Learn to live together, learn the peaceful resolution of conflicts, non-violence, to which learning to discover the other and engagement in joint realisation of projects can contribute;

- Learn to be, to have the ability to form independent and critical thinking, independence of opinion, personal responsibility, and a sense of spirituality and aesthetics (Report of UNESCO, 1998).

Contemporarily, due to the progressive ageing of society ${ }^{2}$, and the economic changes that result in increased insecurity of employment, in education the need for permanent, continuing education is noted. This concept includes comprehensive development, both intellectual as well as social, in all forms and contexts, both in formal as well as informal systems. It is considered crucial to provide educational opportunities to each person who will feel such a need, regardless of age, professional status or place of living (Giza, Sikorska, Ed. 2012, p. 71). In other words, this concept implies the possibility of learning, gaining new skills and competences, changes to the original education - throughout our entire life. And the need for this lifelong learning will be generated by the situation on the labour market, economic changes, or one's own internal needs.

Very highly developed and highly developed societies (Rzymełka-Frąckiewicz, 2012, pp. 33-44; Rzymełka-Frąckiewicz, Wilk, 2014, pp. 13-26), with established democracy, treat the idea of lifelong learning as a normal part of modern societies with the standards of modern market economies. Those are selected countries of Western Europe, North America, Japan, Australia, whereas in countries where democratic processes have not been fully established the concept is still considered marginal. This applies especially to the countries of Central and Eastern Europe. It particularly concerns the generations which finished the stage of compulsory and

2 The ageing of the population indicates that we live longer and longer, and we live to our old age in better and better physical condition, which has a number of consequences for the pension system, health and social care, and economy. 
formal education a long time ago. This situation is well illustrated by the results of international and national studies.

\section{Educational studies}

Educational studies on the relationship between the level of human capital of each country and the rate of their long-term economic growth, which indicates the correlation of education systems and the fate of the graduates in the labour market, conduct research analysis of skills and core competences of respondents. An example of the largest and most widespread international test of academic skills is the Programme for International Student Assessment (PISA). This program analyses such skills as reading comprehension, mathematical reasoning, and reasoning in the natural sciences. The tested skills have been defined quite generally, and are not connected with any particular curriculum. At the same time, the content of tasks is largely rooted in everyday situations. The study involves students at the age of 15 (the main study) as well as parents and school head teachers (a survey). Tests have been performed regularly every three years since 2000. The study results allow for comparisons between the countries participating in the project, provide the opportunity to observe how the abilities have been changing over time. The conclusions of the study are to indicate what elements should be changed or improved in different education systems. PISA test organisation in Poland is supervised by the Institute of Philosophy and Sociology (PAN). On the websites ${ }^{3}$ of the institution there is information about the assumptions, the participating countries, and the results of the study. Among other major international studies on school students' skills there are PIRLS (Progress in International Reading Literacy Study) and TIMSS (Trends in International Mathematics and Science Study).

\section{The Programme for the International Assessment of Adult Competencies- PIAAC}

The most interesting international study of skills, this time not only school youth's, but most of all adults', is the Programme for the International Assessment of Adult Competencies - PIAAC ${ }^{4}$, in which Poland is also involved.

3 PISA Programme in Poland: http://www.ifispan.waw.pl/index.php?lang=pl\&m=page\&pg_id=98

4 Information on PIAAC Programme acquired from the websites: OECD:- http://www.oecd. 
The PIAAC Programme is the largest international survey of adults in the history. It measures the skills and competences that are indispensable to individuals participating in the society and economy of highly developed countries. It also helps to understand better how, in what direction, to transform education systems, all kinds of education, in order to develop the desired skills and competences. The initiator of the study is the international organisation OECD. The presented programme was carried out in the years 2011-2012, on a group (in Poland) of 9366 people between the ages of 16-65, and the first results were obtained in October, 2013. The programme comprised over 20 countries all over the world (Australia, Austria, Belgium, Canada, Cyprus, the Czech Republic, Denmark, Estonia, Finland, Spain, the Netherlands, Ireland, Japan, Korea, Germany, Norway, Poland, Portugal, Russia, Slovakia, Sweden, the United Kingdom, Italy, the USA), and other countries (Argentina, Bulgaria, China, India, Israel, Romania, Singapore, Turkey) consider taking part in the study.

The PIAAC Programme is a response to the growing interest in the skills of adults. In accordance with the provisions of the programme, it is already a common belief that it is the knowledge and skills, and not the level of formal education, which the prosperity of economic development depends on. For this reason, the ways to improve the quality of education and training are sought for.

The innovation of the PIAAC study is to verify real skills rather than the level of formal education. On the basis of the results of these studies, it will be possible to know the actual efficiency of education systems in the world.

PIAAC identifies three groups of key competences:

- literacy - competences associated with reading and evaluation of information contained in various types of texts, i.e.: involvement in reading, understanding and evaluation of the information contained in written texts, and using this information to participate in social life, to achieve one's objectives, and to develop one's own knowledge and potential;

- numeracy - competences related to the interpretation and practical use of mathematical issues in everyday life, i.e.: the ability to use, interpret and analyse mathematical concepts and information expressed in the language of mathematics, for the purpose of responding to and dealing with mathematical challenges that occur in everyday life of adults;

org/general/piaacprogrammefortheinternationalassessmentofadultcompetencies.htm; Education Enthusiasts; the website presents the process and results of a systemic project run by the Educational Research Institute: http://eduentuzjasci.pl/piaac-postpiaac; http://eduentuzjasci.pl/ badania/110-badanie/194-miedzynarodowe-badanie-kompetencji-osob-doroslych-piaac.html 
- problem solving in technology-rich environment - competences related to the use of computers, and the Internet to search for and transform information, i.e.: it relates to the use of digital technology and digital communication tools and networks, to obtain and analyse information, communicate with other and perform practical tasks.

\section{PIAAC results}

As the results of the study show (Umiejętności Polaków... / Skills of Polish people/, $2013)^{5}$, the skill level of Polish people aged 16-65 is lower than the average skill level of the residents of the OECD countries that participated in the study. The Polish score in reading comprehension is within 6 points of the OECD average (267 pts. to 273 pts.), and in the field of mathematical reasoning - 9 points (260 pts. to 269 pts.). The biggest concern about Polish people's skills is in using ICT6, they are lower than in the OECD countries: $38 \%$ of adult Poles have a low level of ICT literacy, and only $19 \%$ a high level - compared to $27 \%$ and $34 \%$ on average in the OECD countries.

In Poland, nearly $15 \%$ of adults have low levels of both reading comprehension skills and mathematical reasoning, and further $13 \%$ - in one of these areas. Almost all of these people have a low level of ICT skills or do not have them at all. At the same time, $14 \%$ of adult Poles achieve very high scores in at least one of the studied areas of skills.

The average skill level is lower among the elderly. In Poland, as in other countries, a decrease in the level of the tested competences is observed in persons over 30 years of age. Polish people aged 16-24, and 55-65, are separated by 32 points in the understanding of the text, and 25 points in mathematical reasoning. $38 \%$ of young people have a high ability to use ICT, among the elderly this percentage is only $3 \%$.

The dependence of skills on education is very strong. In Poland, the difference in the average scores of people with higher education and those with lower secondary education or less is 70 points in the understanding of the text, and 74 points in

5 The report prepared within the systemic project Quality survey and effectiveness of education and institutionalisation of research facilities, co-financed by the European Union through the European Social Fund, realised by the Educational Research Institute.

6 Information and Communication Technology. 
mathematical reasoning. About $37 \%$ of people with higher education have a high level of ICT literacy, compared to $2 \%$ in the group with the lowest education.

Based on the results of the PIAAC study, it can be concluded that low scores obtained by Polish people against the average of the other countries participating in the study, especially among people over 30 years of age, among people with secondary and vocational education, indicates a real problem. Adult Poles rarely take or do not take at all any further education or gain new skills or competences upon completion of the stage of formal and compulsory education. In view of the dynamics of change in the reality in which we live, individuals without proper education adequate to the changing conditions become a group exposed to social exclusion, marginalisation and noticeable impoverishment.

\section{Polish reports on Lifelong Learning}

Similar conclusions are drawn by the authors of the Raport o stanie edukacji 2013 - Licza sie nauczyciele (Report on the State of Education 2013 - Teachers Matter), and the authors of Diagnoza Społeczna 2013 - Rynek pracy i wykluczenie społeczne w kontekście percepcji Polaków (Social Diagnosis 2013 - The Labour Market and Social Exclusion in the Context of the Perception of Polish People).

The former, Raport o stanie edukacji 2013 - Licza się nauczyciele, presents the following conclusions:

"The level of education of Polish people increases: the proportion of people without education or with the lowest level of education decreases, the share of people with higher education increases. These changes result from entering adulthood by the youngest age cohorts, whose skill levels do not differ significantly from those of their OECD peers. However, participation of adults in various forms of learning in Poland is relatively low, and for years it has remained at a similar, unchanged level, and the least likely to improve their competences are people who are not working and with lower levels of education.

In the opinion of Polish people, education is not - as yet at the beginning of the $21^{\text {st }}$ century - a guarantee of employment and career development. Hence, it appears that with the increasing popularity of education at a higher level, to maintain a position on the labour market it will be increasingly important to improve professional qualifications and gain new competences - taking part in lifelong learning (Report on the state of education 2013, 2014, pp. 21-40) ${ }^{7 ”}$.

7 Chapter 1. M. Rokicka, M. Sitek: Wyksztalcenie Polaków / Education of Polish people /. 
The second report, Diagnoza Społeczna 2013 - Rynek pracy $i$ wykluczenie społeczne w kontekście percepcji Polaków (Social Diagnosis 2013 - Labour market and social exclusion in the context of the perception of Polish people) presents the following conclusions:

"In $2011-2013$, only $9.6 \%$ of people aged 25 or older participated in any activity associated with the improvement of their professional qualifications, or other skills, which is slightly less than that indicated by the results of previous studies. The results of the Social Diagnosis 2013 (and previous editions) indicate that adult people continuing education, which is recognised as one of the basic conditions for increasing employability, still constitute a small scope in Poland. It is a worrying signal, as the summary of results of the educational activity of the adult population in Poland, with the structure of population by the level of education and civilization skills, shows disparities regarding the development opportunities of inhabitants of towns and villages, as well as generally people aged 35 and over, and especially those in the immobile age ${ }^{8}$. Differences in the level of education and linguistic skills or the use the Internet between young people and those aged 35 or over, indicate a gap of competences, which deepens with the transition to older age groups" (Social Diagnosis 2013, 2014, pp. 55-80) . $^{9}$

The summary section of Diagnoza Społeczna reads:

"The discrepancy between the demand for educational services, due to the existing level of education, and qualifications of the population - on the one hand, and of technological change and requirements of work resource on the other hand, and the model of educational activity of selected groups of the population, shows a constant need to intensify the process of lifelong learning in Poland. It is necessary to develop various forms of complementary education and improve skills and actions to extend the scope of the use of educational services" (Social Diagnosis 2013, 2014, p. 79).

\section{Conclusion}

Today's reality clearly shows the connection and the relationship between education and the labour market, the ability, flexibility of employment in various

8 The age range comprises working age and includes those who are no longer willing to change jobs, train or retrain to change positions. Immobile age range: from 45 to retirement age (year).

9 Chapter 2. I. Grabowska, I.E. Kotkowska: Aktywność edukacyjna dorosłych członków gospodarstw domowych / Educational activity of adult household members /. 
occupations and obtained earnings. The challenges of today and the upcoming future are the reason why education in the broad sense should prepare people to use current developments of changing civilization, but also involve them in creative and independent participation in social life and active creation of their own future. The mission of the contemporary processes of schooling (formal education) is not only to equip individuals with the necessary knowledge, competences, and skills useful and necessary in the reality of here and now, but also to develop an awareness - individual and social - of self-responsibility for the quality of life. The priority becomes the idea of lifelong learning operationalized, considered a natural, primary and safe form of adaptation to constantly changing conditions in our global reality.

\section{References}

Bauman Z., 2012. O edukacji, Rozmowy z Riccardo Mazzeo / On education, Conversations with Riccardo Mazzeo/. Wrocław: Wyd. Naukowe Dolnośląskiej Szkoły Wyższej.

Diagnoza społeczna 2013 - Rynek pracy i wykluczenie społeczne w kontekście percepcji Polaków / Social Diagnosis 2013 - The Labor Market and Social Exclusion in the Context of the Perception of Polish People I, 2014. Ed. I. E. Kotkowska, Warszawa: Ministerstwo Pracy i Polityki Społecznej i Centrum Rozwoju Zasobów Ludzkich.

Giddens A., Sutton P.W., 2014. Socjologia. Stowa kluczowe /Sociology. Keywords/, Warszawa: Wyd. PWN.

Giza A., Sikorska M., Ed., 2012. Wspótczesne społeczeństwo polskie / Contemporary Polish society/, Warszawa: Wyd. PWN.

Inkeles A., Smith D. H., 1974. Becoming Modern, Cambridge, Mass: Harvard University Press.

K. Ferenz, S. Walasek Ed., 2009. Role wspótczesnego nauczyciela w zmieniającej się rzeczywistości społecznej / The roles of the modern teacher in the changing social reality /, Wrocław: Oficyna Wydawnicza Atut.

Raport o stanie edukacji 2013 - Licza sie nauczyciele / Report on the State of Education 2013 - Teachers Matter/, 2014. Warszawa - Instytut Badań Edukacyjnych,

Report to UNESCO of the International Commission on Education for the Twenty-first Century, under the chairmanship of Jacques Delors, 1998. Learning the Treasure Within, Warszawa.

Rzymełka-Frąckiewicz A., 2012. Znaczenie wykształcenia w wymiarze indywidualnego i globalnego rozwoju społecznego. Polska a Współczynnik Rozwoju Społecznego - Human Development Index (HDI) / The importance of education in the dimension of individual and global social development. Poland and the Human Development Index (HDI)/, "Chowanna", vol. 1 (38).

Rzymełka-Frąckiewicz A., Wilk T., 2014. Logic of some selected concepts in contemporary 
education (between education and perception of committed art/theatre), Toruń: Wyd. Edukacyjne Akapit.

Szczepański M.S., 1999. Modernizacja, W: Encyklopedia Socjologii /Modernisation, In: Encyclopedia of Sociology /, T.2, Warszawa: Oficyna Naukowa.

Szempruch J., 2012. Nauczyciel w warunkach zmiany społecznej i edukacyjnej / The teacher in the conditions of social change and education /, Kraków: Wyd. Impuls.

Sztompka P., 1997. Kulturowe imponderabilia szybkich zmian społecznych. Zaufanie, lojalność, solidarność / Cultural imponderables of rapid social changes. Trust, loyalty, solidarity /, "Studia socjologiczne", no 4.

Sztompka P., 1999. Kulturowe imponderabilia szybkich zmian społecznych. Zaufanie, lojalność, solidarność, W: Imponderabilia wielkiej zmiany. Mentalność, wartości i więzi czasu transformacji / Cultural imponderables of rapid social changes. Trust, loyalty, solidarity, In: Imponderables of great change. Mentality, values and ties at the time of transformation /, Ed. P. Sztompka, Warszawa-Kraków: PWN.

Sztompka P., 2002. Socjologia. Analiza społeczeństwa / Sociology. Analysis of society /, Kraków: Wyd.Znak.

Umiejętności Polaków - wyniki Międzynarodowego Badania Kompetencji Osób Dorostych (PIAAC) / Skills of Polish People - the results of the Programme for the International Assessment for Adult Competencies (PIAAC) /, 2013. Warszawa: Wyd. Instytut Badań Edukacyjnych.

\section{Web pages:}

PISA Programme in Poland: http://www.ifispan.waw.pl/index.php?lang=pl\&m=page\&pg id $=98$

Informacje o programie PIAAC pozyskane ze stron internetowych:

- OECD: http://www.oecd.org/general/piaacprogrammefortheinternationalassessmentofadultcompetencies.htm

- Entuzjaści Edukacji; strona prezentuje przebieg i wyniki projektu systemowego prowadzonego przez Instytut Badań Edukacyjnych:

http://eduentuzjasci.pl/piaac-postpiaac;

http://eduentuzjasci.pl/badania/110-badanie/194-miedzynarodowe-badanie-kompetencji-osob-doroslych-piaac.html

Information on PIAAC Programme acquired from the websites:

- OECD: http://www.oecd.org/general/piaacprogrammefortheinternationalassessmentofadultcompetencies.htm

- Education Enthusiasts; the website presents the process and results of a systemic project run by the Educational Research Institute: http://eduentuzjasci.pl/piaac-postpiaac; http://eduentuzjasci.pl/badania/110-badanie/194-miedzynarodowe-badanie-kompetencji-osob-doroslych-piaac.html 